\title{
APPLICATIONS OF BIOFERTILIZER, AMELIORANT, NPK FERTILIZER ON N- TOTAL, AVAILABLE P, GROWTH AND YIELD OF CORN PLANT IN INCEPTISOLS
}

\author{
Mieke Rochimi Setiawati ${ }^{1}$, Lia Nur Linda ${ }^{2}$, Nadia Nuraniya Kamaluddin ${ }^{1}$ and Tualar Simarmata ${ }^{1}$ \\ ${ }^{1}$ Soil Science Department, Agriculture Faculty of Universitas Padjadjaran, Indonesia. \\ Jl. Raya Bandung Sumedang Km 21 Jatinangor Kab. Sumedang 45363, Indonesia. \\ ${ }^{2}$ Alumni of the Agrotechnology Study Program, Faculty of Agriculture, Universitas Padjadjaran
}

https://doi.org/10.35410/IJAEB.2021.5656

\begin{abstract}
Biofertilizer is a single or consortia of microorganisms added into carrier and applied as a means to improve crop yield. This experiment aimeds to the interaction between $\mathrm{N}$ and $\mathrm{P}$ biofertilizer, ameliorant, compound NPK fertilizer application towards soil total-N, Available-P, and Bisi-2 corn yield grown on Pasir Banteng Inceptisols. This experiment was conducted in the experimental field in Pasir Banteng, Tanjungsari, Sumedang District, Randomized Block Design (RDB) experimental design consisted of various biofertilizer with ameliorant, combinations with 4 levels. The first factors were : a0: (control), a1:1.2 kg ha-1 $\mathrm{N}$ biofertilizer $+1.2 \mathrm{~kg}$ ha-1 $\mathrm{P}$ biofertilizer, a2:2000 kg ha-1 of ameliorant, a3:1.2 kg ha-1 N biofertilizer $+1.2 \mathrm{~kg}$ ha-1 P biofertilizer $+2000 \mathrm{~kg}$ ha-1 of ameliorant. The second factor was NPK dose with four levels (f1:100\%, f2:80\%, f3:60\%, f4:40\%). The total combination were 16 treatments combination and each combination was repeated three times. The results showed biofertilizer, ameliorant, with NPK fertilizer were increase plant height, N-Total soilcontent, cob weight without husk, and corn kernel weight per plant. The use of biofertilizers and ameliorant on corn grown in Pasir Banteng Inceptisols not been able to reduce the dose of NPK fertilizer is used.
\end{abstract}

Keywords: Ameliorant, Inceptisols, corn, biofertilizer, $\mathrm{N}$ total, $\mathrm{P}$ available.

\section{INTRODUCTION}

Corn (Zea mays L.) is the second staple food after rice which is used as a source of carbohydrates and is used as industrial raw material and animal feed. The increasing population and current industrial developments will directly have an impact on increasing demand or consumption of corn. Corn grows well in tropical to subtropical areas, from the lowlands to an altitude of 3,000 m above sea level (asl), with high, medium, to low rainfall of about $500 \mathrm{~mm}$ per year.

The increase in corn productivity every year is related to the use of chemical fertilizers and pesticides that can increase corn productivity, but these chemicals can also cause side effects on the soil, which can reduce soil quality. Dry land is one type of land suitable for planting corn (Mulyani and Las, 2008). The main obstacles that are often encountered in dry land are acid soil reactions, poor nutrients, low organic matter content, high iron and aluminum content that 
Vol. 06, No. 04; 2021

ISSN: $2456-8643$

exceeds plant tolerance limits and are sensitive to erosion so that productivity levels are low (Hidayat et al., 2002).

Inceptisols is one of the soil orders in Indonesia that has the potential for agricultural development such as corn. The area is about 70.5 million ha or $37.5 \%$ of the total land area. Inceptisols generally have a low fertility rate, among others, constrained by an acidic $\mathrm{pH}$, high clay content, and an easily washed surface layer (Sudirja et al., 2018). Inceptisols are one of the soil orders that have limiting factors for nutrient deficiency, namely: $\mathrm{N}, \mathrm{P}, \mathrm{K}, \mathrm{Ca}$, and $\mathrm{Mg}$. Soils in the wet tropics such as Indonesia generally have low organic matter content, have a fairly high clay content (35-78\%), $\mathrm{pH}$ acid to slightly acidic ( $\mathrm{pH} 4.6-5.5)$.

Efforts to increase fertilization efficiency and encourage environmentally friendly planting can be done by utilizing biofertilizers. Biofertilizers are inoculants with active ingredients from living organisms that have the ability to mobilize, facilitate and increase the availability of unavailable nutrients into available forms through biological processes. Decomposers or microbial decomposers are categorized as biofertilizers because they play an active role in converting unavailable or bound nutrients in the form of organic compounds into available nutrients through mineralization or decomposition processes (Simarmata, 2013).

The application of biofertilizers can reduce the use of urea and SP-36 fertilizers by up to $25 \%$ in maize cultivation (Akil et al., 2014). Application of biofertilizer mixed with vermicompost 5 or 10 tons $\mathrm{ha}^{-1}$ increased the $\mathrm{N}$ content in the soil compared to other treatments. The provision of organic matter can increase the supply of organic $\mathrm{C}$ which is a source of energy for Azotobacter sp. (Kennedy et al., 2004). The providing of biofertilizers is expected to be able to help increase the population of beneficial microbes in the soil, support the plant growth, and reduce the use of inorganic fertilizers. Potential biofertilizer groups for organic-based integrated agriculture include $\mathrm{N}$-fixing bacteria (symbiotic and non-symbiotic), P-solubilizing microbes, Ksolubilizing microbes, plant growth promoting rhizobacteria, endophytic bacteria, decomposers microbes and that play a role as a biological agentmicrobes.

The element nitrogen $(\mathrm{N})$ is very important for the formation of protein, stimulates vegetative growth and increases yields, the availability of $\mathrm{N}$ in the soil is one of the important factors to support the growth and development of corn plants. The choice of biological nitrogen provider is to utilize free nitrogen fixing bacteria such as Azotobacter and Azospirillum (Ekawati and Syekhfani, 2005). The application of organic ameliorants is needed on agricultural land which functions to reduce soil acidity, becomes a source of binding cations that are leached due to water flow, as well as a source of energy for microbes in biofertilizer(Adimihardja and Sutono, 2005).

Ameliorants such as biochar are able to reduce soil acidity on acid dry land which is commonly found on agricultural land in Indonesia. Soil acidity in acid dry land is generally caused by high concentrations of aluminum which causes stunted plant growth and reduces crop yields. Inorganic soil improver from natural materials such as agricultural lime, for example, dolomite. Dolomite is used on acid soils and also suffers from a deficiency of $\mathrm{Mg}$, so that in addition to reducing soil acidity, it is also able to increase $\mathrm{Mg}$ nutrients. The use of humic acid 
Vol. 06, No. 04; 2021

ISSN: $2456-8643$

can improve soil fertility because it can bind $\mathrm{Al}, \mathrm{Fe}$, and $\mathrm{Mn}$ ions which are toxic to plants (Khaled and Faw et al., 2011).

The use of inorganic fertilizers in this study is intended as the main source for the availability of nutrients in soil and plants, because the nutrient content in Inceptisols is low and the role of biofertilizers is applied as a facilitator of nutrient supply so that it can be absorbed by plants. Based on the previous description, an experiment is needed to assess biofertilizers, organic ameliorants and NPK inorganic fertilizers on reducing the use of inorganic fertilizers, increasing the total $\mathrm{N}$ soil, $\mathrm{P}$ available, growth and yield corn on Inceptisols from Pasir Banteng.

\section{MATERIALS AND METHODS}

This experiment was carried out at the Experimental Ground of the Center for the Development of Horticultural Seeds and Various Crops in Pasir Banteng, Tanjungsari, Sumedang Regency, West Java with an altitude of $\pm 800 \mathrm{~m}$ above sea level. Inseptisols Pasir Banteng soil has chemical properties of $\mathrm{pH} 5.95$, total soil $\mathrm{N} 0.20 \%, \mathrm{P}_{2} \mathrm{O}_{5}$ Bray $10.19 \%, \mathrm{~K}_{2} \mathrm{O}$ $\mathrm{HCl} 25 \% 25.95 \mathrm{mg} / 100 \mathrm{~g}$. Soil organic-C 2,30\%.

Precipitation type A based on Schmidt and Fergusson. The materials used were corn seeds of Bisi-2 variety. Biofertilizers consisted of isolates of $\mathrm{N}$-fixing bacteria (Azotobacter chroococcum, Azospirillum sp.), Endophytic bacteria isolates, P solubilizing bacteria isolates identified as (Bulkholderia vietnamiensis, and Enterobacter ludwigii). Pikovskaya media, JNFb media, organic ameliorants (compost, biochar, dolomite, humic acid, guano). Carrier of biofertilizers (peat, chicken manure compost, coconut shell compost, additives), NPK fertilizer (15-15-15) with a recommended dose of $350 \mathrm{kgha}^{-1}$ of NPK fertilizer.

This experiment used a factorial randomized block design experimental method consisting of 2 factors, namely the combination treatment of biofertilizer with ameliorant (A) which consisted of 4 levels and the dose of NPK fertilizer (F) with four levels. The total combinations were 16 treatment combinations and were repeated three times, there were total of 48 treatment combinations. The treatmentswere :

Combination of biofertilizer with ameliorant as main plot $(\mathrm{A})$ :

a0 : No treatment (Control).

a1 : $1.2 \mathrm{~kg} \mathrm{ha}^{-1}$ biofertilizer $\mathrm{N}+1.2 \mathrm{~kg} \mathrm{ha}^{-1}$ biofertilizer $\mathrm{P}$

a2 : $2000 \mathrm{~kg} \mathrm{ha}^{-1}$ organic ameliorant

a3 : $1.2 \mathrm{~kg} \mathrm{ha}^{-1}$ biofertilizer $\mathrm{N}+1.2 \mathrm{~kg} \mathrm{ha}^{-1}$ biofertilizer $\mathrm{P}+2000 \mathrm{~kg} \mathrm{ha}^{-1}$ organic ameliorant

Compound NPK Fertilizer Dose (F) :

f1 : $100 \%$ Compound NPK

f2 : $80 \%$ Compound NPK

f3 : $60 \%$ Compound NPK

f4 : $40 \%$ Compound NPK

Observational data were evaluated with the $\mathrm{F}$ test to determine the difference in responses to plant growth and yield from each treatment. The data obtained were analyzed using Microsoft 
Office Excel 2019 software and analyzed for variance (ANOVA) using SPSS version 16.0. If there is a significant effect, then the test is continued with Duncan's multiple distance test (DMRT) at a 5\% significance level.

\section{RESULTS AND DISCUSSION}

\section{Corn Plant Height}

Observation of plant height growth was carried out by measuring plant height from the soil surface to the tip of the highest leaf. Corn plant height at 8 weeks after planting (WAP) showed that the best maize plant height was obtained from the treatment of $1.2 \mathrm{~kg} \mathrm{ha}$ ${ }^{1}$ biofertilizer $\mathrm{N}+1.2 \mathrm{~kg} \mathrm{ha}^{-1}$ biofertilizer $\mathrm{P}+2000 \mathrm{~kg} \mathrm{ha}^{-1}$ amelioran organic fertilizer with $100 \%$ NPK (a3f1). Plants will thrive and obtain optimal results if the nutrients are sufficient. This shows that the application of a combination of biofertilizers, ameliorants, and high doses of NPK fertilizers can increase plant height. It is known that the providing of this combination has a good effect on the height of corn plants in Inceptisol Pasir Banteng soil which has low nutrient content.

Table 1. Corn plant height $(\mathrm{cm})$ at 8 WAP

\begin{tabular}{|lllll|}
\hline (Biofertilizer, & \multicolumn{4}{l}{ NPK Fertilizer } \\
\cline { 2 - 5 } Ameliorant) & $\mathrm{f} 1$ & $\mathrm{f} 2$ & $\mathrm{f} 3$ & $\mathrm{f} 4$ \\
\hline \multirow{2}{*}{ a0 } & $196.00 \mathrm{a}$ & $186.00 \mathrm{a}$ & $176.00 \mathrm{a}$ & $146.00 \mathrm{a}$ \\
& D & C & B & A \\
a1 & $211.67 \mathrm{~b}$ & $202.00 \mathrm{~b}$ & $181.67 \mathrm{~b}$ & $159.00 \mathrm{~b}$ \\
& D & C & B & A \\
a2 & $202.33 \mathrm{a}$ & $183.00 \mathrm{a}$ & $172.67 \mathrm{a}$ & $153.67 \mathrm{ab}$ \\
& D & C & B & A \\
a3 & $220.67 \mathrm{c}$ & $196.33 \mathrm{~b}$ & $196.00 \mathrm{c}$ & $182.67 \mathrm{c}$ \\
\hline
\end{tabular}

Note: Numbers followed by the same letter are not significantly different according to Duncan's test at a 5\% significance level. Uppercase letters are read horizontally, lowercase letters are read vertically.

Biofertilizers will not be effective if there is little or no organic matter in the soil, because microorganisms will use the organic matter as an energy source to provide nutrients for plants. The content of soil organic matter used in this study is relatively low, so balanced fertilization is needed so that biofertilizercan have an effect on soil and plants (Simanungkalit, 2001). The use of biofertilizers is more profitable in the long run. Continuous application of biofertilizercan improve soil fertility, so that the soil will be healthy and can affect the availability of nutrients for plants and can reduce the use of synthetic fertilizers.

\section{Number of Leaves}

Based on Table 2, it is known that the application of $1.2 \mathrm{~kg} \mathrm{ha}^{-1}$ biofertilizer $\mathrm{N}+1.2 \mathrm{~kg}$ ha $^{-1}$ biofertilizer $\mathrm{P}+2000 \mathrm{~kg} \mathrm{ha}^{-1}$ organic ameliorant produced the largest number of leaves, 
namely 20.17 leaves. In the application of inorganic fertilizers, the highest number of leaves was obtained in the $\mathrm{f} 1$ and $\mathrm{f} 2$ treatments. The bigger the plant height, the more stem segments that will be a place for leaves to come out (Putri et al., 2011). In general, maize has the same growth pattern, but the time interval between growth stages and the number of leaves that develop can be different (Subekti et al., 2007).

Table 2. Average number of leaves of corn plants 8 WAP

\begin{tabular}{|c|c|}
\hline Treatments & $\begin{array}{l}\text { Number of leaves at } 8 \\
\text { WAP (leaves) }\end{array}$ \\
\hline 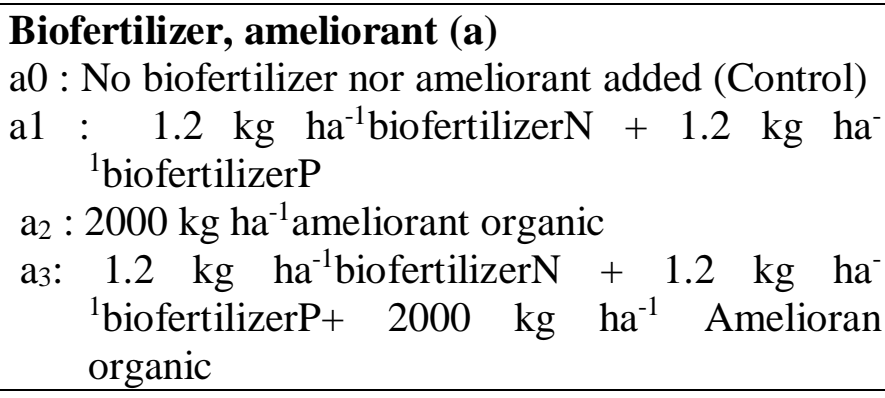 & $\begin{array}{l}17.08 \mathrm{a} \\
17.67 \mathrm{a} \\
17.67 \mathrm{a} \\
20.17 \mathrm{~b}\end{array}$ \\
\hline Dosage NPK (f) & \\
\hline $\begin{array}{l}\text { f1 }: 100 \% \text { NPK compound } \\
\text { f2 }: 80 \% \text { NPK compound } \\
\text { f3 }: 60 \% \text { NPK compound } \\
\text { f4 }: 40 \% \text { NPK compound }\end{array}$ & $\begin{array}{l}19.67 \mathrm{c} \\
18.91 \mathrm{c} \\
17.83 \mathrm{~b} \\
16.17 \mathrm{a}\end{array}$ \\
\hline
\end{tabular}

Note: Numbers followed by the same letter are not significantly different according to Duncan's multiple distance test at $5 \%$ significance level

The addition of $\mathrm{N}$ nutrients to the soil is related to the formation of leaf chlorophyll which stimulates plant leaf growth. Leaves are the main photosynthetic producing organs, because their function is to receive light captured by chlorophyll. If the leaves grow well, the light received by the leaves will also affect to the absorption of nutrients in plants (Widayanti, 2008). The number of leaves cannot be used as a reference for determining the optimum dose because the number of leaves is more influenced by genetic factors than environmental factors (Cui et al., 2017).

\section{N-Total Soil}

The results of statistical tests showed that there was an effect of the application of biofertilizers, ameliorants, and NPK on the N-Total parameters of the soil. A3f1 treatment (1.2 $\mathrm{kg}$ ha $^{-1}$ biofertilizer $\mathrm{N}+1.2 \mathrm{~kg} \mathrm{ha}^{-1}$ biofertilizer $\mathrm{N}+2000 \mathrm{~kg} \mathrm{ha}^{-1}$ Organic ameliorant + Compound NPK (100\%) gave a higher effect than other treatment combinations on $\mathrm{N}$ Total soil Inceptisols Pasir Banteng.

Table 3. Total $\mathbf{N}$ Content (\%) in Inceptisols from Pasir Banteng at 8 WAP

(Biofertilizer, NPKFertilizer 


\begin{tabular}{|lllll|}
\cline { 2 - 5 } ameliorant) & f1 & f2 & f3 & f4 \\
\hline \multirow{2}{*}{ a0 } & $0.50 \mathrm{~b}$ & $0.36 \mathrm{~b}$ & $0.31 \mathrm{~b}$ & $0.22 \mathrm{~b}$ \\
& $\mathrm{C}$ & $\mathrm{B}$ & $\mathrm{AB}$ & $\mathrm{A}$ \\
$\mathrm{a} 1$ & $0.52 \mathrm{~b}$ & $0.42 \mathrm{c}$ & $0.23 \mathrm{~b}$ & $0.18 \mathrm{~b}$ \\
& $\mathrm{C}$ & $\mathrm{B}$ & $\mathrm{A}$ & $\mathrm{A}$ \\
$\mathrm{a} 2$ & $0.16 \mathrm{a}$ & $0.15 \mathrm{a}$ & $0.13 \mathrm{a}$ & $0.08 \mathrm{a}$ \\
& $\mathrm{C}$ & $\mathrm{BC}$ & $\mathrm{B}$ & $\mathrm{A}$ \\
$\mathrm{a} 3$ & $0.72 \mathrm{c}$ & $0.55 \mathrm{~d}$ & $0.56 \mathrm{c}$ & $0.50 \mathrm{c}$ \\
& $\mathrm{B}$ & $\mathrm{A}$ & $\mathrm{A}$ & $\mathrm{A}$ \\
\hline
\end{tabular}

Note: Numbers followed by the same letter are not significantly different according to Duncan's test at a 5\% significance level. Capital letters are read Horizontal. Lowercase letters are read vertically.

The increase in the population of $\mathrm{N}$-fixing bacteria due to the application of biofertilizerwill be directly proportional to the total $\mathrm{N}$ content in the soil because $\mathrm{N}$-fixing microbes have a role in providing $\mathrm{N}$ in the soil. The combination treatment of biofertilizers, organic ameliorants, and NPK fertilizers contributed to an increase in total N in the soil. The application of biofertilizeror ameliorants must be combined with NPK to increase total soil N (Rukmana, 1995).NPK fertilizer is easily soluble in water that can cause the $\mathrm{N}$ in the fertilizer to dissolve in the soil and will produce nitrate $\left(\mathrm{NO}_{3}{ }^{-}\right)$and ammonium $\left(\mathrm{NH}_{4}{ }^{+}\right)$in the soil solution that can be absorbed by plants and increase the total $\mathrm{N}$ of the soil.

\section{P-Available Soil}

Based on Table 4, the results of statistical analysis showed that the application of biofertilizeror ameliorants did not increase the available $\mathrm{P}$ in the soil. On the other hand, the application of NPK fertilizer has an effect on increasing the available $\mathrm{P}$ of the soil. This can be due to the less than optimal performance of phosphate solubilizing bacteria contained in biofertilizergiven to plants.

Table 4. Content of available P (ppm P) in Inceptisols from Pasir Banteng at 8 WAP

\begin{tabular}{|c|c|}
\hline \multicolumn{2}{|r|}{ P-available(ppm $P$} \\
\hline $\begin{array}{l}\text { Biofertilizer, ameliorant (a) } \\
\text { a0 : No biofertilizer nor ameliorant added } \\
\text { (Control) } \\
\text { a1:1.2 kg ha }{ }^{-1} \text { biofertilizer } \mathrm{N}+1.2 \mathrm{~kg} \mathrm{ha}^{-1} \\
\quad \text { biofertilizer } \mathrm{P} \\
\mathrm{a}_{2}: 2000 \mathrm{~kg} \mathrm{ha}^{-1} \text { ameliorant organic } \\
\mathrm{a}_{3}: 1.2 \mathrm{~kg} \mathrm{ha}^{-1} \text { biofertilizer } \mathrm{N}+1.2 \mathrm{~kg} \mathrm{ha}^{-1} \\
\text { biofertilizer } \mathrm{P}+2000 \mathrm{~kg} \mathrm{ha}^{-1} \text { ameliorant organic }\end{array}$ & $\begin{array}{l}13.60 \mathrm{a} \\
12.76 \mathrm{a}\end{array}$ \\
\hline \multicolumn{2}{|l|}{ Dosage NPK (f) } \\
\hline $\begin{array}{l}\text { f1 }: 100 \% \text { NPK compound } \\
\text { f } 2: 80 \% \text { NPK compound }\end{array}$ & $\begin{array}{l}18.95 \mathrm{c} \\
13.21 \mathrm{~b}\end{array}$ \\
\hline
\end{tabular}


Vol. 06, No. 04; 2021

ISSN: $2456-8643$
f3 : $60 \%$ NPK compound
$11.07 \mathrm{a}$
f4 : $40 \%$ NPK compound
9.70 a

Note: Numbers followed by the same letter are not significantly different according to Duncan's test at a 5\% significance level.

The treatment of $100 \%$ NPK compound fertilizer increased the highest available P content of the soil (18.95 ppm P). The application of high inorganic P fertilizers into the soil can cause the performance of microbes to produce phosphatase enzymes to be less than optimal. Phosphatase plays a role in dissolving organic $\mathrm{P}$, in this study the $\mathrm{P}$ given is inorganic $\mathrm{P}$ which can be dissolved by organic acids. The available $\mathrm{P}$ element is needed for the development of plant roots. Element $\mathrm{P}$ is needed by the leaves in the process of photosynthesis. The role of BPF in breaking down $\mathrm{P}$ nutrients is known through the mechanism of secretion of low molecular weight organic acids such as oxalic succinate, fumarate, and malic. These organic acids will react with phosphate-binding materials such as $\mathrm{Al}^{3+}, \mathrm{Fe}^{3+}, \mathrm{Ca}^{2+}$, or $\mathrm{Mg}^{2+}$ to form stable organic chelates so that they are able to free bound phosphate ions and therefore can be absorbed by plants (Suriadikarta and Simanungkalit, 2006).

The high availability of $\mathrm{P}$ from inorganic $\mathrm{P}$ fertilizers caused the growth and activity of phosphate solubilizing microbes to be less than optimal. Microbes will be active if the availability of $\mathrm{P}$ is low but $\mathrm{P}$ insoluble is high. Microbes have an important role in the availability of $\mathrm{P}$ in the soil for both plants and other microbes that support the nutrient cycle in the soil. In this experiment, the application of biofertilizercontaining phosphate solubilizing microbes aims to increase the availability of $\mathrm{P}$ for corn plants, but the inorganic fertilizers given are not insoluble $\mathrm{P}$ such as rock phosphate.

The application of biofertilizerdid not show a significant effect because the plants had received nutrients from inorganic fertilizers. The role of phosphate solubilizing microbes is not only to increase P solubility, but also to produce plant growth hormones (Kartika et al., 2017). The availability of organic $\mathrm{P}$ in plants is highly dependent on the mineralization activity carried out by microbes (Stevenson, 1994). The application of organic fertilizer showed no significant difference to the increase in available P of Inceptisols from Pasir Banteng soil.

\section{Corn Crop Yield}

In Table 5, it shows that the application of organic ameliorant (a2) given NPK fertilizer increased from $\mathrm{f} 2$ to $\mathrm{f} 1$ did not cause an increase in the weight of corn cobs without husks. Meanwhile, in the application of biofertilizerand organic ameliorants (a3), the increasing doses of NPK fertilizers caused an increase in the weight of the cob without husksfrom the f 2 to $\mathrm{f} 1$ level. The heaviest weight of cob without husk was obtained from the combination treatment of $1.2 \mathrm{~kg} \mathrm{ha}^{-1}$ biofertilizer $\mathrm{N}+1.2 \mathrm{~kg} \mathrm{ha}^{-1}$ biofertilizer $\mathrm{N}+2000 \mathrm{~kg} \mathrm{ha}^{-1}$ organic ameliorant $+100 \%$ compound NPK (a3f1). The heaviest weight of the cob without husk was produced from a combination of all fertilizer and ameliorant treatments applied to the Inseptisols Pasir Banteng soil, this was because the soil fertility in the study site did not support optimal maize yields. The soil macro nutrients that are not sufficient for the needs of corn plants in the planted plots causes the need of fertilizer in high inputs. 
Table 5. Cob weight (g) without husk per plant

\begin{tabular}{|lllll|}
\hline (Biofertilizer, & \multicolumn{4}{l}{ NPK Fertilizer } \\
\cline { 2 - 5 } Ameliorant) & $\mathrm{f} 1$ & $\mathrm{f} 2$ & $\mathrm{f} 3$ & $\mathrm{f} 4$ \\
\hline $\mathrm{a} 0$ & $1769.00 \mathrm{a}$ & $1659.00 \mathrm{a}$ & $1592.00 \mathrm{a}$ & $1547.00 \mathrm{a}$ \\
& $\mathrm{C}$ & $\mathrm{B}$ & $\mathrm{AB}$ & $\mathrm{A}$ \\
$\mathrm{a} 1$ & $2128.00 \mathrm{~b}$ & $1858.00 \mathrm{~b}$ & $1726.00 \mathrm{~b}$ & $1650.00 \mathrm{~b}$ \\
& $\mathrm{D}$ & $\mathrm{C}$ & $\mathrm{B}$ & $\mathrm{A}$ \\
$\mathrm{a} 2$ & $1796.67 \mathrm{a}$ & $1661.33 \mathrm{a}$ & $1620.00 \mathrm{a}$ & $1598.33 \mathrm{ab}$ \\
& $\mathrm{C}$ & $\mathrm{C}$ & $\mathrm{AB}$ & $\mathrm{A}$ \\
$\mathrm{a} 3$ & $2178.00 \mathrm{~b}$ & $1797.00 \mathrm{~b}$ & $1647.33 \mathrm{a}$ & $1642.00 \mathrm{~b}$ \\
& $\mathrm{C}$ & $\mathrm{B}$ & $\mathrm{A}$ & $\mathrm{A}$ \\
\hline
\end{tabular}

Note: Numbers followed by the same letter are not significantly different according to Duncan's test at a 5\% significance level. Uppercase letters are read horizontally, lowercase letters are read vertically.

The macronutrients contained in NPK fertilizers are needed for plant growth and development which are absorbed in the form of anions and cations (Sutedjo, 2008). N and P are needed by plants because of enzymatic reactions in plant metabolism processes, which are assisted by microbial activity, so that nutrients are more easily absorbed by plants, so that they can be maximized in the absorption process. The number of internodes formed due to the elongation of the stem and the increase in the number of leaves will allow the number of cobs to be formed as well (Subandi et al., 2017).

Based on Table 6, the results of statistical analysis showed that the independent effect of biofertilizeradded with or nor ameliorant had an effect on increasing the weight of corn kernels per plant. The application of $1.2 \mathrm{~kg} \mathrm{ha}^{-1}$ of biofertilizer $\mathrm{N}+1.2 \mathrm{~kg} \mathrm{ha}^{-1}$ of biofertilizer $\mathrm{P}+2000$ $\mathrm{kg} \mathrm{ha}^{-1}$ of organic ameliorant resulted in the weight of corn kernels per plant which was not different from the application of biofertilizers.

Table 6. Weight of corn kernels per plant

\begin{tabular}{|c|c|}
\hline Treatments & $\begin{array}{l}\text { Weight corn kernels } \\
\text { per plant }(\mathrm{g})\end{array}$ \\
\hline $\begin{array}{l}\text { Biofertilizer, ameliorant (a) } \\
\text { a0 : No biofertilizer nor ameliorant added (Control) } \\
\text { a1 : } 1.2 \mathrm{~kg} \mathrm{ha}^{-1} \text { biofertilizer } \mathrm{N}+1.2 \mathrm{~kg} \mathrm{ha}^{-1} \\
\quad \text { biofertilizer } \mathrm{P} \\
\mathrm{a}_{2}: 2000 \mathrm{~kg} \mathrm{ha}^{-1} \text { ameliorant organic } \\
\text { a3 : } 1.2 \mathrm{~kg} \mathrm{ha} \text { biofertilizer } \mathrm{N}+1.2 \mathrm{~kg} \mathrm{ha}^{-1} \\
\text { biofertilizer } \mathrm{P}+2000 \mathrm{~kg} \mathrm{ha}^{-1} \text { ameliorant organic }\end{array}$ & $\begin{array}{l}1048.14 \mathrm{~b} \\
981.00 \mathrm{a} \\
1052.17 \mathrm{~b}\end{array}$ \\
\hline
\end{tabular}




$$
\begin{array}{|l}
\text { f1 : } 100 \% \text { NPK compound } \\
\text { f2 : } 80 \% \text { NPK compound } \\
\text { f3 : } 60 \% \text { NPK compound } \\
\text { f4 : } 40 \% \text { NPK compound }
\end{array}
$$

$1078.16 \mathrm{~d}$

$1045.50 \mathrm{c}$

$997.67 \mathrm{~b}$

$964.33 \mathrm{a}$

Note: Numbers followed by the same letter are not significantly different according to Duncan's multiple distance test at $5 \%$ significance level

The biofertilizer given to corn plants contains $\mathrm{P}$ solubilizing bacteria (Bulkholderia vietnamiensis, and Enterobacter ludwigii). The use of $\mathrm{P}$ solubilizing bacteria is an effort to increase the availability of $\mathrm{P}$ for plants so that it can substitute the use of inorganic $\mathrm{P}$ fertilizers. According to the results of research by Soelaeman et al. (2017) the application of a combination of fertilizers with biochar or P solubilizing biofertilizer, or manure on corn plants in acid dry land, significantly increased the growth and yield of corn.

P-solubilizingbiofertilizercontain bacteria that can provide $\mathrm{P}$ nutrients in the soil through the process of dissolving potential $\mathrm{P}$ by P-solubilizing microbial groups, so that they become available to plants (Whitelaw, 2000). The presence of phosphate solubilizing microbes with organic acids can increase the solubility of unavailable $\mathrm{P}$ into available $\mathrm{P}$ in the soil, will cause an increase in $\mathrm{P}$ uptake by plants which will also increase the yield of corn (Hasanudin and Bambang, 2004). Besides that, biofertilizeralso contain $\mathrm{N}$-fixing bacteria, $\mathrm{N}$-fixing bacteria found in biofertilizerincluding Azotobacter chroococcum, Azospirillum sp. can supply $\mathrm{N}$ through the activity of the nitrogenase enzyme in fixing $\mathrm{N}_{2}$ from the air into the form of $\mathrm{NH}_{4}{ }^{+}$which can be directly absorbed by plants (Aisyah et al., 2006).

NPK fertilizer with a high dose of $100 \%$ of the recommended dose resulted in the highest weight corn perplant. The availability of nutrients is related to the corn kernels filling process (Akil, 2013). The absorbed nutrients will be accumulated in the leaves to become protein and contribute to the formation of corn kernels. Nutrient deficiency greatly affects the growth and development of the cobs and will even reduce the number of kernelsin one cob due to the shrinking of the cobs and lower yields (McWilliams et al. 1999). P deficiency will cause corn cobs to be imperfect and small (Hardjowigeno, 2010). Munawar (2011) also emphasized that N deficiency in corn can cause a reduction in the number of cobs per unit area and number of kernels. If the accumulation of metabolic products in the formation of kernelswill increase, so that the kernelsformed have the maximum size and weight. This can happen if the nutrient needs are met which causes the metabolism to run optimally (Singh al., 2005).

\section{CONCLUSION}

Based on the results of the study, there was following conclusions:

1) There was an interaction between biofertilizeror organic ameliorants with NPK in increasing plant height, N-total soil, weight of cobs without husk. The independent treatment of inorganic fertilizers had an effect on the available P-available in the soil. The independent treatment of biofertilizeror ameliorants and inorganic NPK fertilizers affected the number of leaves and kernels of corn on Inceptisols from Pasir Banteng. 
2) The application of $1.2 \mathrm{~kg} \mathrm{ha}^{-1}$ biofertilizer $\mathrm{N}+1.2 \mathrm{~kg} \mathrm{ha}^{-1}$ biofertilizer $\mathrm{P}+2000 \mathrm{~kg} \mathrm{ha}$ ${ }^{1}$ amelioran + compound NPK $(100 \%)$ was able to produce a weight of $2178.00 \mathrm{~g}$ of cobs without husks per plant, but has not been able to reduce the use of compound NPK fertilizers on Inceptisols from Pasir Banteng.

\section{ACKNOLEDGMENT}

This research was funded by Academic Leadership Grant (ALG) from Universitas Padjadjaran. We are also thankful to our students for supporting us during experiment at laboratory.

\section{REFERENCES}

Adimihardja A. dan Sutono, S.2005. Sloping land erosion control technology. Editor: Marham. Proceedings of Dry Land Management Technology Towards Productive and Environmentally Friendly Agriculture: 103 - 145. Bogor, 4-5 Juni 2005

Aisyah D., S. Tien Kurniatin, S. Maryam. 2006. Soil Fertility and Fertilization. Department of Soil Science, Agriculture Faculty Unpad. pp : 7-18

Akil, M. 2013. N, P, and K Nutrient Needs for Hybrid Corn Plants on Dry Land in Gowa Regency. Cereal National Seminar.

Cui M, Jia B, Liu H, Kan X, Zhang Y, Zhou R, Li Z, Yang L, Deng D and Yin Z. 2017. Genetic Mapping of the Leaf Number above the Primary Ear and Its Relationship with Plant Height and Flowering Time in Maize. Frontiers in Plant Science. Vol. 8 No. 1437.

Ekawati I, Syekhfani. 2005. Decomposition of rice canopy by mixed culture of cellulolytic bacteria and nitrogen fixing.J. Pembangunan Pedesaan. 5:120-128.

Hardjowigeno, S. 2010. Ilmu Tanah (Soil Science). Penerbit Akademika Pressindo, Jakarta.

Hidayat, A. and A. Mulyani. 2002. Dry Land Management Technology Towards Productive and Environmentally Friendly Agriculture.Center for Soil and Agroclimate Research and Development. Agricultural Research and Development Agency. pp 1-34.

Kartikawati, A., Trisilawati, O., and Darwati, I. 2017. Utilization of Biofertilizer (Biofetilizer) in Spice and Medicinal Plants. Jurnal Prespektif, 16(1), 33-43

Kennedy, I.R., A.T.M.A. Choudhury and M.L. Kecskes. 2004. Non-symbiotic bacterial diazotrophs in crop farming systems: can their potential for plant growth promotion be better exploited. Soil Biol. Biochem. 36: 1229-1244

Khaled H. and Faw H.A. 2011. Effect of Different Levels of Humic Acids on the Nutrient Content, Plant Growth, and Soil Properties under Conditions of Salinity. Soil \& Water Res., 6, (1): 21-29.

McWilliams, D.A., D.R. Berglund and G.J. Endres. 1999. Corn Growth and Management Quick Guide. North Dakota Cooperative Service, Fargo.

Mulyani, A., dan Las, I., 2008. Potential land resources and optimizing the development of bioenergy-producing commodities in Indonesia.27(1). Bogor. http://203.190.37.42/publikasi/p3271085.pdf.

Munawar, A. 2011. Kesuburan Tanah dan Nutrisi Tanaman. (Soil Fertility and Plant Nutrition)Bogor: IPB Press

Putri, H., S. Auzan dan H. Netti. 2011. Effect of Giving Several Concentrations of Bio Sugih Complete Liquid Organic Fertilizer (POCL) on Plant Growth and Yield of Sweet Corn. Agriculture Faculty Universitas Andalas, Padang. 
Rukmana, R. 1995. Usaha Tani Jagung. (Corn Farming Business.) Kanisius. Yogyakarta.

Simanungkalit RDM. 2001. Application of biofertilizers and chemical fertilizers: an integrated approach.Buletin Agrobiol. 42(2): 56-61.

Simarmata, T., B. Joy., andNana D. 2013. The role of agricultural research and development in the biofertilizer industry. Papers at the National Seminar on Fertilization Technology and Recovery of Degraded Land BBSDLP, Bogor.

Singh, N., K.S. Shandu, and M. Kaur. 2005. Physicochemical properties including granular morphology, amylase content, swelling and solubility, thermal and pasting properties of starches from normal, waxy, high amylase and sugary corn. Progress in Food Biopolymer Research 1:43-55.

Stevenson, F.J. (1994). Humus Chemistry: Genesis, Composition, Reactions. (2nded). New York: Wiley.

Subandi, M. Hasani, S. Satriawan, W. 2017. Efficiency of Nitrogen and Phosphorus Fertilizers with the Addition of Biological Fertilizers on Corn (Zea mays L.) Varieties of Pertiwi3.Volume X No. 1 ISSN 1979-8911. Jurusan Agroteknologi, Fakultas Sains dan Teknologi, UIN Sunan Gunung Djati .Bandung.

Subekti, N.A., R.Efendi, dan S. Sunarti. 2007. Plant Morphology and Corn Growth Phase. In Corn, Production Engineering and Development. Jakarta: Center for Food Crops Research and Development., pp. 16-28.

Sudirja, R. Joy,B. Yuniarti, A. Trinurani, E. Mulyani, O., and Mushfiroh, A. 2018. What are the Soil Chemical Properties of Inceptisols and Soybean Yield (Glycine max L.) Due to Ameliorant Application. $\quad$ SoilREns. 15(2), 198-205. https://doi.org/10.24198/soilrens.v15i2.15766.

Suriadikarta, R. D. M. dan D. A. Simanungkalit. 2006. Organic Fertilizer and Biological Fertilizer. Center for Research and Development of Agricultural Land Resources, Agency for Agricultural Research and Development.Bogor.

Sutedjo, M. M. 2008. Pupuk dan Cara Pemupukan. (Fertilizer and Fertilization Method) Rineka Cipta, Jakarta

Whitelaw. 2000. Growth promotion of plants inoculated wth phosphate solubilizing fungi. Adv. Agron 69: 99-151.

Widayanti, A. 2008. Effects of Cutting and Fertilization on Production and Quality of Borreria alata as High Quality Forage.Institut Pertanian Bogor, Bogor. 